\title{
Bir Kent İmgesi Olarak Bafra Nokulu
}

\section{Cafer ÖZDEMIR*}

\begin{abstract}
ÖZ
Toplumsal bellek ürünü olan imgeler, doğal veya işlenmiş olarak bir milletin özgünlüğünü yansitırlar. Küreselleşen dünyada daha çok anlam kazanan imgeler, günümüzde kültürel mirasın geleceğe taşınması yanında kendisinden farklı alanlarda istifade etmeyi zorunlu kılmıştır. Dünyadaki tek tipleşme, yöresel ve özgün ürünlere olan ilgiyi ve farkındalığı artırmış; bu yolla toplumsal refah, istihdam, ekonomik fayda gibi amaçlarla kültüre dayalı üretim faaliyetleri önem kazanmıştır. Yerel ve bölgesel şekilde başlayan uygulamalar öncelikle ait olduğu bölgenin imgeleri olarak değer kazanmış, bunlar bazen ülkelerin mirasları olarak UNESCO tarafindan dünya kültür mirasına dâhil edilmiştir.
\end{abstract}

Samsun ilinin en büyük ilçelerinden biri olan Bafra, verimli toprakları, zengin tarımsal faaliyetleri ve canlı ticaret hayatıyla öne çıkmaktadır. Samsun'a çok yakın konumda bulunan, modern bir kent havasının hakim olduğu ilçede geçmişten günümüze zengin bir toplumsal belleğin hâkim olduğu görülür. Pidesi, nokulu, kaymaklı lokumu, dondurması, şenlikleri ve festivalleri, tarihî ve mimarî eserleri ile zengin bir kültürel mirasa sahiptir. Her biri Bafra'nın imgesi olabilecek bu ürünlerin hak ettiği değeri bulamadığ görülür.

Çalışmamızda mutfak kültürünün bir unsuru olarak yörede "şerbetsiz tatlı" olarak adlandırılan Bafra nokulu mevzu edilmiştir. Kelimenin kökeni araştırıldıktan sonra yörede geleneksel nokulu tespit edip bunu yaygınlaştıran kişilerin bilgileri doğrultusunda tarif verilmiştir. Geleneksel üründe hamurun ince açılması, margarin kullanılmaması, iç malzeme olarak ceviz ve üzüm kullanılması ve yerken ağıda dağılması

Doç. Dr., Ondokuz Mayıs Üniversitesi, Eğitim Fakültesi, Türkçe ve Sosyal Bilimler Eğitimi Bölümü, Samsun/Türkiye

E-posta: cafer.ozdemir@omu.edu.tr, ORCID: 0000-0002-5794-5828,

DOI: 10.32704/erdem.2021.81.093

Makale Gönderim Tarihi: 05.12.2020 * Makale Kabul Tarihi: 29.11.2021 * (Araştırma Mk.) 
gibi temel nitelikler nokulun öne çıkan özellikleridir. Nokulun Bafra kent merkezi ve köylerde eskiden beri bilindiği, yaklaşık yüz elli yıllık bir geçmişi olabileceği öngörülmüştür. Eskiden bayramların vazgeçilmez ürünü iken günümüzde buna ilave olarak misafir ağırlama, belirli günlerde ikram ve hediyeleşme geleneğinin bir parçası olarak Bafra'nın sosyo-kültürel hayatında önemli bir yer kazanmıştır. Yakın zamanda kaymaklı lokum ve nokul üretim tesislerinin açılması ve bu alanda kadın istihdamı ile kültür ekonomisinde kendine yer bulmuştur. Çeşitli kurumların çalışmaları ve bireysel çabalarla nokul, Bafra kent imgesi olma yolunda ilerlemektedir. Yerelde Bafra imgesi olmak, aynı zamanda Samsun imgesi olma anlamı taşır. Bu anlamda ilin çeşitli çabaları da mevcuttur.

Nokulun yaşatılması ve yöresel bağlamda yaygınlaşmasında yapılan çalışmalar etkili olmuşsa da ulusallaşma ve markalaşma sürecinde çeşitli projelere ve atılımlara ihtiyaç duyulmaktadır. Bu bağlamda ilçe içerisinde ve yörede gerçekleştirilen bazı etkinliklerde ve festivallerde nokulun tanıtımı yapılmalı, daha sonra ülke çapında yapılacak çalışmalarla bu yöresel ürüne bir kimlik ve aidiyet kazandırılmalıdır. Nokul gibi ortak bellek ürünlerinin kültür endüstrisi alanına taşınması, yöreselin tanınması ve küreselleşen dünyada özgünlükleri geleceğe taşıma bağlamında büyük bir işlevi yerine getirecektir.

Anahtar Kelimeler: Kültür, kent imgesi, Bafra nokulu, tanitım, aktarım. 


\title{
Bafra Nokul As A City Image
}

\begin{abstract}
Images that are the product of social memory reflect the originality of a nation as natural or processed. Images, which gain more meaning in the globalizing world, have made it compulsory to benefit from them in different areas besides carrying the cultural heritage to the future. Uniformization in the world has increased the interest and awareness of local and original products; in this way, culture-based production activities have gained importance for purposes such as social welfare, employment and economic benefit. The practices that started locally and regionally gained value primarily as the images of the region to which they belong, and these were sometimes included in the world cultural heritage by UNESCO as the heritage of the countries.
\end{abstract}

Bafra, which is the largest of Samsun's out-of-center districts, stands out with its fertile lands, rich agricultural activities and vibrant commercial life. It is seen that a rich social memory from past to present is dominant in the district, which is located very close to Samsun and where a modern urban atmosphere prevails. It has a rich cultural heritage with its pita, nokul, delight with, ice cream, festivities and festivals, historical and architectural works. It is seen that these products, each of which can be the image of Bafra, do not find the value they deserve.

In our study, Bafra nokul, which is locally referred to as a dessert without sherbet, has been discussed as an element of cuisine culture. After the origin of the word was searched, a description was given in line with the knowledge of the people who determined the traditional view of nokul in the region. The main features of the traditional product, such as thinning the dough, not using margarine, using walnuts and grapes as filling materials, and dispersing them in the mouth while eating, are the prominent features of nokul. It has been observed that nokul has been known in the city center of Bafra and the villages for a long time and may have a history of about 150 years. While it was an indispensable product of holidays in the past, today it has gained an important place in the socio-cultural life of Bafra as a part of the tradition of hosting guests, treats on certain days and giving gifts. Recently, it has found a place in the cultural economy with the opening of delight with cream and nokul production facilities and women's employment in this field. With the works of individual and various institutions, it is about to become the city image of Bafra. Being the image of Bafra also means also being the image of Samsun. In this sense, the province also has various efforts. 
Although the studies carried out have been effective in keeping nokul alive and spreading it in the local context, various projects and breakthroughs are needed in the process of nationalization and branding. In this context, the promotion of nokul should be made in some activities and festivals held in the district and in the region, and then an identity and belonging to this local product should be gained through country-wide studies. Moving common memory products like nokul to the field of culture industry will fulfill a great function in terms of recognizing the local and carrying the originality to the future in the globalizing world.

Keywords: Culture, city image, Bafra nokul, promotion, transference. 


\section{Giriş}

Jokul kelimesi "nukl” kelimesinden gelmektedir. Sözlüklerde "Mayalı 1 hamurun içine ceviz, findık, susam, üzüm konularak yapılan bir çeşit çörek (Eren,1999: 300), aynı nitelik ve içeriğe sahip olan "şekerli ya da şekersiz bir çeşit çörek" (Derleme Sözlüğü/IV, 2009: 3255), "Mayalı hamurdan, içine ceviz, kuru üzüm, findık, susam, kıyma vb. gibi katıklar konularak pişirilen, bayram günleri çocuklara ve eşe dosta ikram edilen bir tür çörek; içli çörek." (Çağbayır, 2007: 3561) şeklinde açıklanmaktadır. Bunun yanında Fuzulî Bayat kelimenin "meze, çerez" (2008: 351) anlamlarına geldiğini kaydeder. Mehmet Kanar, Eski Anadolu Türkçesi Sözlüğü adlı eserinde nükûl kelimesinin Arapça "çerez" anlamında kullanıldığını belirtir ve Süheyl ü Nevbahar'da "Süciden içüben nukuldan yidi/Sunup havz içinde elini yudu" geçen beytinde çerez anlamına geldiğini belirtmektedir (2011: 523). Sözlüklerde nokul genellikle çörek olarak açıklanmasına karşın Samsun yöresinde bu anlamıla belleklerde yer almamakta, daha çok "şerbetsiz tatlı" olarak tarif edilmekte ve bilinmektedir. Fakat nokulun "çerez" şeklinde açıklanan anlamına uygun olarak tüketilen bir yiyecek olduğunu söyleyebiliriz. Çünkü nokul, çay veya çeşitli soğuk içecekler ile birlikte tüketilmektedir.

Bafra'da olmasa da Samsun merkezde kelimenin aslının nokul mu yoksa lokul mu olduğu konusunda tereddütler vardır. Kelimenin aslının nokul/nukul olmasına rağmen Anadolu ağızlarında kelime başlarında sıklıkla karşılaştığ1mız "l, n" değişiminden dolayı yörede her iki şekliyle telaffuz edilmektedir.

\section{Nokulun Yapılışı}

Bafra'da nokulun yapılışı ile ilgili farklı tarifler mevcuttur ve buna bağlı olarak malzemelerde farklı ölçüler kullanılır. Yine de gelenekselleşmiş tarifi belirlemek gerekir. Geleneksel Bafra nokulunun tekrar canlandırılmasında etkili olan ve Bafra'da bu anlamda ilk ticari işletme sayılan Zalpa'nın kurucularından Ferda Karagöl Demir' in nokul tarifini esas aldık. Kendisi Bafral1dır ve geleneksel nokulun Bafra'da yaygınlaşmasında önemli bir yere sahiptir. Kendisinden edindiğimiz bilgilere göre yaklaşık beş kilo gelen bir tepsi nokulun tarifi şu şekildedir: Bir kase (bir su bardağından biraz fazla) yoğurt, yarım kase sıvı yağ, bir buçuk kase su, bir yemek kaşığı kuru maya, bir tatlı kaşı̆̆ı tuz, 600 gram ceviz içi, 400-450 gram kuru üzüm ve 2 avuç (200 gram civarı) toz şeker hazırlanır. Bir yemek kaşığı şeker mayayla ıslanır ve maya kabarır. Hazırlanan malzemeler karıştırılır, üzerine un ilave edilir. Unun belli bir ölçüsü yoktur, hamur kulak memesi yumuşaklığı, kıvamı kazanana kadar 
un katılır. Hazırlanan hamur mayalanması için bekletilir. Hamur yaklaşık 10-15 dakika bekletilir ve kabarmadan 2-3 adet hamur yumağı oluşturulur. $\mathrm{Bu}$ yumaklara zıval adı verilir. Bu hamurlar masa üzerinde ortalama 1,5 metre uzunluğunda çok ince olarak açılır. Açılan hamur sıvı yağla yağlanır ve üzerine ceviz içi, üzüm ve toz şeker karışımı serpiştirilir. Daha sonra bunlar yassı rulo haline getirilir. Her yufkada bu eylem iki defa gerçekleştirir. Rulo haline getirilmiş karışımlar 7-8 cm uzunluğunda kesilir ve pişirme tepsisine dizilir. Üzerlerine yumurta karışımı sürülür ve fırında kızarıncaya kadar pişirilir. 170 derecede yaklaşık 30-35 dakikada pişirilmelidir. Hasan Yiğit'e göre hamurun ince açılması, yendiğinde ağızda dağılması, ceviz içi ve üzümle yapılması ve üzerine bal veya pekmez sürülmesi Bafra nokulunun orijinal özellikleridir. Nuran Güngör köylülerin ellerindeki malzeme doğrultusunda üzüm, findık, ceviz, sıvı yağ ve tereyağı kullandıklarını ve bunları taş firınlarda pişirdiklerini belirtmiştir. Ferda Karagöl Demir, orijinal Bafra nokulunda tereyağ kullanılmadığını, fakat sipariş isteyenlerin arzusuna göre tereyağ kullanılarak yapıldığını da ifade etmiştir. Ayrıca babaannesinin hamurun üzerine sadece yumurta sarısı sürdüğünü, günümüzde bu karışıma pekmez de katılarak daha koyu bir kırmızılık verenler olduğunu belirtmiştir.

Bafra'da klasik nokul, ceviz ve üzüm karışımından elde edilmekle birlikte ürünün farklı çeşitleri de yapılmaktadır. Sadece cevizli, sadece üzümlü, ceviz yerine daha ucuz olduğu için sadece findıklı veya sade yapılanları da mevcuttur. Nokulda esas olan "kıyır kıyır" olmasıdır. Bütün kaynak kişilerimizin üzerinde 1srarla durdukları konulardan biri hamurun çok ince açılması ve yendiğinde ağızda dağılması ile ilgilidir.

Bafra'da yapılan nokulun fiyatları değişkenlik göstermekle birlikte iç malzemesinin bolluğu ve kaliteli olması gibi hususlar dikkate alındığında ortalama fiyat aralığı 2020 yılı için kilogram başına 50-65 Türk lirası arasındadır.

\section{Nokulun Tarihi}

Kendisi Bafralı olan ve Bafra'da Halk Eğitim Merkezi Müdürlüğü gibi görevlerde bulunan araştırmacı yazar Hasan Yiğit ile yaptığımız görüşmede kendisi Bafra'nın tarihi, mutfak kültürü ile ilgili araştırmalar yaptığını ifade etmiştir. Hasan Yiğit, nokulu neneleri ve dedelerinin bildiğini, onların da büyüklerinden öğrendiğini belirterek bu yöresel yiyeceğin en az iki yüz yıldır ilçede bilindiğini, öncesinin olma ihtimalinin de güçlü olduğunu belirtmiştir. Evliya Çelebi'nin Seyahatnamesi'nde nokulun olmamasını, seyyahın Bafra'da kısa süre kalıp sadece ileri gelenlerle görüşüp ayrılmasına 
bağlamaktadır. Zalpa adlı işletmenin sahibi Ferda Karagöl Demir, Bafralı'dır ve nokul yapımını babaannesinden öğrenmiştir. $\mathrm{O}$ da annesinden öğrenmiş̧tir. Nokulun tekrar diriltilmesi ve yaygınlaştırılmasında etkili olan şahısların ifadelerinden hareketle yüz elli y1llık bir tarihi geçmişe gitmek mümkündür. Fakat elde herhangi bir kayıt olmadığ için yüz elli yıl öncesine ait ifadelerin daha çok söylemde kaldığını ifade edebiliriz.

\section{Nokulun Yayılışı}

Nokulun yayılışından önce çıkış noktasının tespit edilmesi yerinde olacaktır. Yaptığımız görüşmelerde kaynak kişilere bu tatının Bafra merkeze mi yoksa köylere mi ait olduğu sorusu yöneltilmiştir. Nokulun Bafra'da tekrar diriltilmesi ve yaygınlaştırılmasında büyük emeği olan Hasan Yiğit, nokulun aslında köylere ait olduğunu, buradan şehir merkezine taşınma ihtimalinin güçlü olduğunu belirtmiştir. Köylerde sadece Ramazan ve Kurban Bayramı'nda, evlerin önünde bulunan taş firınlarda yapılmaktadır ve bayrama özgü bir tatlıdır. Bayramlarda köylerde nokul yapılmayan ev yok gibidir. Bafra merkezde yaklaşık son elli yıldır görülmektedir, bu durum 1980 sonrası kırsaldan kente göç ile açıklanabilir. Bafra'nın nüfusunun yüzde sekseni köylerde yaşarken 1980 sonrası kentleşme nedeniyle şehir merkezine gelen köylüler nokulu da şehre taşımışlar ve zamanla şehir merkezinde bu yiyeceğin yaygınlaşmasını sağlamışlardır.

Yöresel ürünlerin hammaddeleri genellikle yörede yetiştirilmektedir. Oysa Bafra nokulunda kullanılan kuru üzüm burada üretilmemektedir. Hasan Yiğit, çok eskiden beri Bafra'nın ticaret hayatının canlı olduğunu, bu nedenle üzüm tedarikinin çok kolay olduğunu ifade etmiştir.

Hasan Yiğit'in görüşlerine paralel olarak Nuran Güngör, nokulun köylerde yaygın olduğunu, daha sonra şehirde tanındığını belirtmiştir. Alaçam ilçesinin Bafra'ya yakın köylerinde de nokulun yaygın olduğunu ifade etmiş̧tir. Bafra, 1923 yılında yapılan Mübadele öncesinde Rumların ikamet ettikleri yerleşim birimlerinden biridir. Bir dönem Yunanistan'dan Bafra'ya atalarının yaşadıkları yerleri gezmek için Rumların geldiğini ve Bafra'da nokulu görünce "Aa nokul” diye tepki verdiklerini belirtmiştir. Hatta Rumlar kendi atalarının da nokul yaptıklarını belirtmiştir. Bafra'dan Yunanistan'a giden Türklerin de giderken hediye olarak nokul götürdüklerini, oradaki Rumların bunu tanıdıklarını ifade etmiştir. Burada nokulun Rum kaynaklı olabileceği akla gelebilir. Fakat Yunanistan'da sadece Türkiye'den göç eden büyüklerin yaptıklarının belirtilmesi ve artık unutulması, yeni nesillere aktarımın yapıl- 
maması, ayrıca Bafra'da yaygın olarak devam etmesi göz önüne alındığında Rumların bu yiyeceği Türklerden öğrendikleri sonucuna varmak mümkündür. Mübadele öncesi Bafra'da yaşayan Rumların nokulu bilmeleri göz önüne alınırsa nokulun en az yüz elli yıllık bir geçmişe sahip olduğu çıkarımı rahatlıkla yapılabilir.

Köylerde istisnasız bütün evlerde dinî bayramlar öncesinde hazırlanması ve yöresel yiyeceklerin daha çok kırsal ürünü olması nedeniyle nokulun, önce köylerde bilindiğini, daha sonra şehirde tanındığını söylemek mümkündür. Hasan Yiğit'in görüşleri bu ifadelerimizi desteklemektedir. Bafra merkezde yaşayan Rumların nokulu bilmelerinden hareketle, en az yüz yıldır şehir merkezinde de bilindiğini tespit etme imkânına sahibiz.

Bafra merkezde ve köylerde bilinmesine rağmen pek revaçta olmayan, insanların dikkatini çekmeyen hatta unutulmaya yüz tutan nokul, 2010'lu yıllarda Bafra Halk Eğitim Merkezi müdürlügü yapan Hasan Yiğit’in çabaları ile tekrar dikkatleri üzerine çeker. Orijinal Bafra nokulunun yapılışını tespit eden Hasan Yiğit, öncelikle nokulu bilen insanlara Halk Eğitim aracılığı ile nokulun nasıl yapıldığını öğreten kurslar düzenler ve onların usta öğreticilik belgesi almasını sağlar. Bununla da yetinmeyerek üç kadın girişimcinin bir araya gelip Zalpa adında kaymaklı lokum ve nokul evi üretimi yapan ve satan bir iş yeri açmalarını teşvik eder. Kursları yaygınlaştırarak insanlara geleneksel Bafra nokulunun nasıl yapıldığını öğretir ve bir anlamda geleneksel tatlının yapılışı hakkında bir standardın oluşmasını sağlar. Daha sonra Zalpa'nın kurucularından Nezahat Şahin kendi adını taşıyan nokul ve lokum evini açar. Bu arada Bafra merkezde ticari işletme olsun veya olmasın nokul üreten insanlar nokul yapmaya ve satmaya başlarlar. Hatta son yıllarda ekmek firınlarında da yapılmaya başlanan nokul her yerde görülür. Zalpa ve Nezahat Şahin adlı işletmelerin internet siteleri vasıtası ile yerelden genele açılma çabaları sonuç verir ve günümüzde her iki işletme de nokulu hem Türkiye'nin çeşitli yerlerine hem de ülke dışına pazarlama imkânına kavuşurlar.

Uzun yıllardır Bafra'da usta öğreticilik yaptığını belirten Nuran Güngör, Bafra Halk Eğitim Merkezi'nin nokulun öğretilmesinde kurslar düzenlediğini, kendisinin buralarda usta öğetici olarak görev yaptığını belirtmiştir. Yüzün üzerinde kişiye nokul yapımını öğretmiştir. Bir dönem Bafra Halk Eğitim Merkezi, Bafra Belediyesi ve İşkur ile işbirliği yaparak nokul yapımı eğitimi düzenlemiştir. Bu proje kapsamında üretilen nokullar Bafra'da satışa sunulmuştur. Zalpa'nın sahibi olan Ferda Karagöl Demir, elliden fazla kişi- 
ye orijinal Bafra nokulunu öğrettiğini belirtmiştir. Günümüzde Halk Eğitim Merkezi nokul öğretimi ile ilgili olarak kurslar düzenlemeye devam etmektedir. Hatta Bafra Hasan Çakın Mesleki ve Teknik Anadolu Lisesi, Yiyecek Hizmetleri Bölümü 2020 yılında nokul üretimine başlamış ve gerek şehir içi gerekse şehir dışı siparişlere cevap vermeye başlamıştır. Okul idaresi, amaçlarının sadece ticari faaliyet olmadığını, öğrencilere nokul yapımını öğreterek Bafra kültürüne hizmet etmeyi de amaçladıklarını belirtmiştir. $\mathrm{Bu}$ yiyeceğin gelecek kuşaklara aktarılıp Türkiye'ye, daha sonra dünyaya tanıtılması gerektiği düşüncesinden hareketle https://www.okuluretimi.com" adında internet sitesi kurmuşlardır. Site vasıtası ile ürettikleri nokulları pazarlamaya başlamışlardır. Okul ayrıca 20.10.2020 tarihinde Türk Patent ve Marka Kurumu'ndan 'Zühre'nin Nokulları" adıyla patent almıştır. Bafra'da eğitim kurumlarının nokulun tekrar geleneksel bir yiyecek olarak tanıtılmasında büyük katkısı vardır. Daha sonra hem bireysel ticari işletmelerin hem de devlet kurumlarının nokula sahip çıkarak onu özelde Bafra'nın, genelde Samsun'un bir imgesi bağlamında dikkate değer çalışmalar yaptıklarını görüyoruz. Burada geleneksel Bafra nokulu markasının korunmasına yönelik büyük gayret gösterilmektedir.

Hasan Yiğit'e göre nokul önce Bafra'da ortaya çıkmış, daha sonra Sinop'ta yaygınlaşmıştır. Sinop'ta üretilen nokul Bafra'dakinden farklıdır. Sinop nokulunun hamuru kalın açılmakta ve yendiğinde ağızda dağılmamaktadır. Sinop ve Bafra arasındaki mesafenin yakın olması nokul konusunda etkilenmeyi akla getirmektedir. Fakat her ne kadar aynı isimle anılmış olsa da her iki yörenin nokul yapılışları birbirinden farklılık arz eder. Sinop yöresel mutfağı konusunda yapılan çalışmalarda nokula da yer verilmektedir. Nadide Afra Genç ve Yılmaz Seçim çalışmalarında Bafra'da nokul yapılışında kullanılan malzemelere değinip bayramlarda yapıldığını belirtmişlerdir (2019: 312). Bu çalışmadaki verilerle Bafra nokulu özelliklerinin örtüştüğü görülmektedir. Fakat bazı illerdeki nokul yapılışını karşılaştıran diğer bir çalışmada şu ifadelere yer verilmiştir: "Samsun nokulu ile Sinop nokulu, içerdiği malzemeler açısından çok benzer unsurları söz konusudur. Sinop ilinde yapılan sadece üzümlü- cevizli nokul değil, kıymalı ve yoğurtlu çeşidi de olması Sinop gastronomisinin zenginliğini de göstermektedir.” (Karaçar, Doğancili, Ak, 445, erişim: 26.11.2020). Adı geçen çalışmada Bafra nokulunda margarinin kullanıldığ 1 belirtilmişse de geleneksel Bafra nokulu yapımıyla uğraşan kaynak kişilerle yaptığımız görüşmelerde margarinin asla kullanılmadığını belirtmişlerdir. Ferda Karagöl Demir ise Sinop nokulunun burma börek gibi yapıldığını ve börek havasında olduğunu, ayrıca $20-30 \mathrm{~cm}$ 
uzunluğunda kesildiğini ifade etmiştir. Ona göre Sinop nokulu orijinal nokul olarak kabul edilemez. Genel anlamda Sinop nokulunun kıymalısının da yapılması, hazırlanan ruloların yuvarlak şekilde sarılması ve üzerine susam konulması bakımından bir börek olarak hazırlandığını söylemek mümkündür. Oysa Bafra nokulunu hazırlayanlar nokulun börek değil, şerbetsiz bir tatlı olduğu konusunda hemfikirdirler. Bu açıklamalar her iki yörenin nokulunun farklı olduğunu ortaya koyar. Bu farklılıktan dolayı her iki nokul da yakın tarihlerde tescil belgesi almışlardır. Samsun Büyükşehir Belediyesi, Türk Patent ve Marka Kurumu'na başvurarak 06.11.2017 tarihinde "Bafra Nokulu" adıyla mahreç işaretli coğrafi ürün belgesi almıştır. Sinop Ticaret ve Sanayi Odası da 15.12.2017 tarihinde aynı kurumdan "Sinop Nokulu" adıyla coğrafi işaret tescil belgesi almıştır (https://online.turkpatent.gov.tr/ trademarksearch/pub/trademark_result\#trademark_result). Her iki nokulun birbirine yakın tarihlerde belgelendirilmesi, yöredeki kurumlar arasında bir rekabet olduğunu göstermektedir. Coğrafi ürün belgesinin çok geç alınması bu tatlıya gereken önemin uzun yıllar gösterilmediğini kanıtlamaktadır.

Yörede yeniden canlandırma faaliyetleri neticesinde nokul sınırlarını genişletmeye başlamış ve yavaş yavaş Samsun merkezde de yaygınlaşmışıtır. Bu durumu Bafralı üreticilerin Samsun merkezde nokul üretimi yapmaları ve zaman içerisinde nokula olan rağbetin artması ile açılamak mümkündür. Günümüzde Samsun il merkezinde pastanelerin veya firınların birçoğunda nokul üretildiğini ve satıldığını görmek mümkündür. Nokul Samsun merkezde orijinal adı olan Bafra nokulu adıyla bilinmektedir. Aynı malzemeler kullanılmış olsa da Samsun merkezde yapılan nokulların daha büyük olduğunu, Bafra nokulu gibi ağızda dağılmadığını söylemek mümkündür. Nuran Güngör, Samsun merkezde yapılan nokulların orijinal Bafra nokulu olmadığını, sadece adının kullanıldığını, nokula benzetilmeye çalışıldığını ifade etmiştir. Samsun merkezde yaygınlaşmasında Bafra'nın nokula sahip çıkması ve etkili tanıtımların payı büyüktür. Hatta Bafra nokulunun coğrafi işaret belgesinin Samsun Büyükşehir Belediyesi tarafından alınmış olması, merkezin hem Bafra nokuluna sahip çıktığını hem de onun olduğunu kabul ettiğini göstermektedir. Fakat Samsun Valiliği ve Samsun İl Kültür ve Turizm Müdürlüğü’nce 2011 hazırlanan Samsun kitapçığının Bafra ile ilgili bölümünde, nokulun Bafra tatları arasında yer alması ve hamurun içine ceviz ve üzüm karışımı konularak yapılması (2011: 131) haricinde başka bir bilgi verilmemesi ve hiçbir görselinin olmaması büyük bir eksikliktir. 


\section{Nokulun Sosyo-Kültürel Hayattaki Yeri}

Kaynak kişiler, ürünün geçmişten günümüze Bafra'da insanların hayatında önemli bir konumu olduğuna, Ramazan ve Kurban bayramları öncesinde Bafra'da her evde nokul yapıldığına sıklıkla vurgu yapmışlardır. Ayrıca nokulun bir börek olmayıp şerbetsiz bir tatlı olması da üzerinde durulan bir husustur. Bu durumu Türk kültüründe dinî bayramlarda tatlı hazırlanması ve misafirlere ikram edilmesi geleneğinin bir tezahürü olarak düşünebiliriz. Tatlı bulma imkanlarının kısıtlı olduğu bir dönemde eldeki ürünlerin harmanlanması neticesinde pratik olarak hazırlanan bu yiyeceğin, yokluk döneminde ortaya çıkma ihtimali de muhtemeldir. 19. yüzyılda Türklerin yaşadığ 1 zorlukları ve yoklukları göz önüne aldığımızda nokulun, bu yüzyılda ortaya çıkma ihtimali de güçlenmektedir. Kaynak kişilerin bu konudaki söylemleri de düşüncemizi desteklemektedir.

Nokul Anadolu Türklerinin beslenme alışkanlıklarına da uygundur. Sofralarında hamur işi yiyecekleri eksik etmeyen Türklerin bu geleneklerine uygun olarak Bafra'da böyle bir yiyecek üretmeleri son derece doğaldır. Ne yazık ki yazılı kaynaklarda bir bilgiye rastlanılmaması, nokulun geçmişine dair öngörülerin sözlü kaynakların bilgileri ekseninde yapılmasını zorunlu kılmıştır. Ferda Karagöl Demir, köylerde tarlada çalışan kadınların nokulu yanlarında azık olarak götürdüklerini, dinî bayramlar öncesinde mutlaka nokul yapıldığ 1 belirtir. Ona göre nokul hem Bafra şehir merkezinin hem de köylerinin bildiği geleneksel bir şerbetsiz tatlıdır. Eskiden sınırlı zamanlarda yapılırken günümüzde özellikle 2010 yılından sonra Bafra' da çok yaygınlaşmış ve hem sosyal hayatın hem de kültürel hayatın bir simgesi olmuştur. Çeşitli toplantılarda, özel günlerde ve hediyelik olarak oldukça yaygın bir konuma gelmiştir. Bafra'ya özgü kaymaklı lokumun tekrar canlandırılmasına paralel olarak nokul da ilçede ticaret hayatının bir parçası konumuna gelmiştir.

Nuran Güngör, nokulun artık sadece bayramlarda üretilmediğini, Bafra insanının günlük yaşamının bir parçası olduğunu, hediye aracı, misafire ikram unsuru, mevlit ve dua toplantılarının (özellikle şehir merkezlerinde evlilik, çocuk sahibi olma vb. nedenlerle yapılan dinî amaçlı bir araya gelmeler) temel malzemesi olduğunu ifade etmiştir. Hatta özel günlerin dışında ailelerin günlük olarak tüketmek amacıyla nokul aldıkları veya ürettikleri bilinmektedir. $\mathrm{Bu}$ durum yöresel bir yiyeceğinin popüler hale gelmesi bağlamında değerlendirilebilir.

Eskiden sadece dinî bayramlar için hazırlanan (Y1lmaz, 2019: 43) nokul günümüzde sosyal ve kültürel hayatın bir parçası haline gelmiştir. Bu durum 
Bafralıların hem yöresel yiyeceklerine sahip çıkmaları hem de nokulu sevmeleri ile ilgilidir. Kültürel bir imge olan nokulun ekonomik hayatın bir parçası olması ve insanların bundan para kazanmaya başlaması, ürünün kültürel ekonomik imgeye dönüşmesi açısından dikkate değer bir örnektir.

\section{Nokulun Kültür Ekonomisindeki Yeri}

1979-2010 yılları arasında uzun bir süre Bafra'da Halk Eğitim Merkezi Müdürlüğü görevini yerine getiren ve kendisi de Bafralı olan Hasan Yiğit'in Bafra'nın imgelerinin tekrar canlandırılması ve gelecek kuşaklara aktarılmasında büyük emeği vardır. Nokul da bu çabaların sonucunda Bafra'da tekrar yaygınlaşmış ve onun teşvikiyle üç kadın girişimci Zalpa adında kaymaklı lokum ve nokul evi açmışlardır. Zalpa'nın günümüzdeki sahibi bu üç kadın girişimciden Ferda Karagöl Demir'dir. Diğer ortak Nezahat Şahin buradan ayrılarak kendi adını taşıyan yeni bir işletme açmıştır. Üçüncü ortak Nuran Güngör ise başta nokul olmak üzere yöresel yemekler ve imgeler konusunda usta öğreticiliğini sürdürmektedir.

Zalpa, nokulun kültürel ekonomik bir imge olmasında Bafra'da önemli bir yere sahiptir. İş yeri ile aynı adı taşıyan bir internet sitesi kuran Ferda Karagöl Demir, nokulun da yer aldığı yöresel lezzetleri yurt içi ve dışına pazarlamaktadır. İşyerinin ve ürünlerin tanıtımını facebook ve instagram gibi sosyal medya platformlarında gerçekleştirmektedir. 2014 yılında kaymaklı lokum ve nokulun yer aldığ 1 tanıtım filmi hazırlatmıştır. Zalpa'da aylık $200 \mathrm{~kg}$ üzeri nokul yapılmakta ve Türkiye'nin değişik yerlerine gönderilmektedir. Ferda hanım, yöresel imgelerin tanıtımı amacıyla İstanbul, Ankara, Antalya, İzmir, Bursa, Kayseri gibi yerlerde gerçekleştirilen festivallere ve tanıtım günlerine sıkça katılmıştır. Hatta İstanbul ve Ankara'da gerçekleştirilen tanıtım günlerine ve festivallere Bafra Ticaret Odası ve Bafra Belediyesi ile birlikte katılmıştır. Burada küçük paketlere konulan nokullar tanıtım amaçlı dağıtılmıştır.

Nokulun ticaretini yapan ikinci işletme, sahibinin adını taşıyan Nezahat Şahin Bafra Kaymaklı Lokum Evi'dir. Yöresel ve ulusal televizyon kanallarında yer alan programlarda sıklıkla yer alan, kendi adını taşıyan internet sitesi ve sosyal medya hesaplarından tanıtımını yapan Nezahat Şahin, Bafra'ya ve Türkiye'nin her yerine nokul satışı yapmaktadır. Hasan Yiğit, her iki işletmenin de günümüzde orijinal Bafra nokulu yaptıklarını ifade etmiştir. Bu iki işletme yanında bazı üreticiler de kendi siteleri üzerinden nokul pazarlamaya devam etmektedir. Bunun yanında evlerde üretilen nokulların da özellikle şehir merkezinde talep edenlere pazarlandığı bilinmektedir. 
Bugün Bafra' da ekmek firınları, pastaneler ve müstakil lokum ve nokul evleri, nokul üretimini yaygın olarak yapmaktadır. (Fotoğraf 8) Bu durum taleple ilgilidir. Nokulun Bafra'nın günlük yaşamında çok tüketilmesi ve bir değer ifade etmesi yaygınlaşmasına zemin hazırlamıştır. Ferda Karagöl Demir, günümüzde Bafra'da bazı ekmek firınlarında yapılan nokulların orijinal Bafra nokulu olmayabileceğine dikkat çekmiştir. Bu durum ilçe içerisinde artan taleple ilgilidir. Ayrıca nokul yapılışının eğitimini almadan yapılan üretimler yöresel ürünün geleneksel halini bozmaktadır.

Yörede kadın istihdamı anlamında önemli bir yere sahip olan nokul, kültürel bir nesnenin imge haline geldikten sonra nasıl ekonomik bir nesneye dönüşebileceğinin açık bir örneğidir. Özellikle yerel ve ulusal basında, sosyal medya platformlarında, video sitelerinde yer alan yüzlerce içerik, Bafra nokulunun ilçenin adıyla da anılarak yaygınlaşmasını ve bir kent imgesi haline gelmesini sağlamıştır. Bu süreçte Bafra Halk Eğitim Merkezi ve Bafra Belediyesi'nin büyük katkıları olmuştur. Yerel kurumların destekleri ve teşvikleri kırsal kalkınmada önemli bir yere sahiptir. Özünel'e göre uluslararası sözleşmelerin amacı yalnız yönetimlerle değil, sivil toplum örgütleri ve özel sektörle de iş birliği yaparak evrensel barış ve uyuma katkı sağlayan, sürdürülebilir, katılımcı bir kültürel miras algısı yaratmaktır (2013: 17). Bu açıdan adı geçen kurumların yöresel ürünler üzerinden bir ekonomik faaliyet yaratmaları ve insanlara istihdam alanı sunmaları, UNESCO'nun somut olmayan kültürel mirasın yaşatılması ilkesine uygun olduğu gibi küreselleşen dünyada farklılıkların yaşatılmasına öncülük etmesi bağlamında da değerlidir.

\section{Bafra/Samsun Kent İmgesi ve Nokul}

Küreselleşmenin kültürel ögeleri yok ettiği günümüz dünyasında yerel ve özgün değerlerin ve ürünlerin önemi giderek artmaktadır. Bu sebeple öncelikle yöre içinde bir anlam değeri taşıyan her türlü değerin tespit edilip işlenmesi, kayıt altına alınması, üretim imkânlarının çeşitlendirilmesi, kültürel ekonomik bir imge haline dönüştürülmesi gerekmektedir. Kültürel belleğe ait bir ürünün yaşatılması, yaygınlaştırılması ve bir imge haline getirilerek ona yeni anlamlar yüklenmesi günümüzde küreselleşme karşısında yapılan önemli adımlar olarak görülür. Fakat ulusallaşmamış, küresel dünyaya adım atamamış bir kültürel bellek ürününün uzun soluklu yaşama şansı azdır. Bunun için kültürel unsurların yerelden ulusala ve nihayet küresele açılan pencerelerini aralamak gerekir. Nebi Özdemir, kentsel imgelerden istifade edilmesi ve onların araştırılmasında yapılması gerekenleri üç aşama halinde 
ortaya koyar: Birinci aşama kültürel belleğin/bilgi bankasının oluşturulmas1dır. İkincisi tasarlama, çağdaş ve etkili yorumlarla imgelerin yaratılmasıdır. Üçüncüsü ise marka olarak kullanımı, ekonomik katma değer oluşturmak gibi çok yönlü kullanımını içeren değerlendirmedir (2008: 19). Tanımlama, işleme ve değerlendirme şeklinde özetleyebileceğimiz bu üç aşama, yerelden küresele uzanan çizginin kısa bir formülünü de vermektedir.

Her yörenin kendine özgü yerel, ulusal veya uluslar arası hale gelmiş meşhur halk bilimsel ürünleri vardır. Ulusal kanıt olarak nitelenebilecek olan bu ürünler bir imge olarak seçilmiş, meşhurlaşmış, işlenmiş ve üzerinde uzlaşı1mış kültürel verimler olarak karşımıza çıkmaktadır. (Oğuz, 2002: 59). Burada dikkat edilmesi gereken nokta, imge haline gelen ürünün mevcut konumu üzerinde düşünülmesi, işlenmesi, çeşitli tasarımlarla zenginleştirilmesi ve yaygınlık kazandırılmasıdır. Hiçbir ürün mevcut halini koruyarak küreselleşen dünyada varlığını devam ettiremez. Bu yüzden ürünlerin doğal imge halinde kullanılması yanında tasarımlarla zenginleştirilmesi de büyük önem taşımaktadır.

Bafra nokulu hakkındayapılan çalışmalara baktığımızda, ürünün geleneksel yapılışının tespit edilip bu konuda ortak düşünce oluşturularak ilçenin bir imgesi haline geldiğini, bu açıdan kültürel veri tabanına kaydedildiğini söylemek mümkündür. Ürünün coğrafi işaret belgesi almas1, yöresel veri taban1na ait olduğunun göstergesidir. (Fotoğraf 9) Ürünün geleneksel halinin tespit edilmesinde Hasan Yiğit'in büyük katkıları olmuştur. Ürün bu doğal haliyle "Bafra nokulu" markası ile özdeşleşmiştir. Yine onun ileri görüşlü destekleme çalışmaları ile ürün, ilçede bir katma değer oluşturacak yöresel ekonomik bir imge haline de getirilmiştir. Hatta bugün hem ilçe içerisindeki talebi karşılamak hem de ülkenin birçok bölgesine gönderilmek amacıyla üretilmesi ilçede ticari hayatı da canlandırmıştır. Özellikle internet siteleri aracılığı ile satış yapılması, yöresel ürün festivallerine katılım ürünün ülke çapında tanınmasına aracı olmuştur. Hatta yöresel ve ulusal gazete haberleri ve televizyon programları da bu sürece katkı sağlamıştır. Burada ürünün sadece doğal bir imge olarak algılandığının altını çizilmelidir. Fakat nokul ile ilgili çeşitli tasarımlar ve değerlendirme aşamaları üzerinde düşünülmemiştir.

Bafralıların nokula sahip çıkmaları profesyonel düzeyde gerçekleşmemiştir. Nokulun imge olma yolunda büyük eksiklikleri bulunmaktadır. İlçede kültürel ve ekonomik hayatın bir parçası olan bu ürün, Samsun merkez hariç diğer ilçelerde bilinmemektedir. Bu durum küresele giden yolda yöresel tanınırlığın göz ardı edilmesi anlamına gelmektedir. Oysa Bafralı işletmelerin 
ilçelerde tanıtım programları düzenleyerek veya yerel festivallere katılarak ürünü tanıtmaları gerekir. Yöresel tanıtım, hem Bafra'nın hem de Samsun'un bir imgesi olarak ürünün sahiplenilmesini de beraberinde getirecektir.

Kültürel belleğe ait bir ürünün imgeleşme sürecinde farklı alanlarda kullanımı, çeşitli tasarımlarının yapılması, çağdaş ve etkili yorumlarla reklamın bir parçası olması ve bir marka olarak pazarlanması gerekmektedir. Bu bağlamda nokulun işlenmemiş bir ürün olduğu söylenebilir. Ticari hayatın eskiden beri güçlü olduğu ilçede işletmeler yöresel imgelere duyarsız kalmıştır. Nokulun Bafra'nın çeşitli kurumlarında isminin yer alması, magnet ve anahtarlık gibi hediyelik eşya ürünlerinde gösterilmesi, çeşitli işletmelerin logolarında kullanılması, popüler dergilerde, turizm ve gastronomi dergilerinde yer almas1, televizyon ve internet reklamlarında konu edinmesi, Bafra'nın kendine has otobüs firmalarının üzerinde veya logolarında reklamının yapılması gibi destekleyici çalışmalara ihtiyaç duyulduğu görülmektedir. Bazı imgelerin ait oldukları yerin markalaşmasında önemli bir yeri vardır. Dolayısıyla imgenin her alanda tanıtımına ve yaygınlık kazandırılmasına ihtiyaç duyulmaktadır.

Nokul, Somut Olmayan Kültürel Mirasın (SOKÜM) Korunmas1 Sözleşmesi’nin halk mutfağının yerel bilgi ve becerilerle üretilen yemekler kategorisinde değerlendirilmektedir. Mutfak kültürünün toplumların beslenme alışkanlıkları ile doğrudan ilişkili olması ve kültürel yapı ile sıkı münasebeti, nokulun farklı ve özgün kimliği yansıtması açısından bir değer olarak görülmesi gerekir. UNESCO tarafından kabul edilen SOKÜM'ün Somut Olmayan Mirasın Korunması ve Kültürel İfadelerin Çeşitliliğinin Korunması ve Geliştirilmesi Sözleşmesi, somut olmayan kültürel miras alanında bireylerin kültür aktarıcılığına işaret etmekte ve kültürel ögelerin kültür endüstrisi alanına taşınmasının önemine vurgu yapmaktadır. Bu yaklaşım ürün merkezli algıyı üretim lehine değiştirmekte ve üretim bağlamının değerliliğini ortaya çıkarmaktadır (Oğuz 2009: 95). Bafra'da nokulun öğretimi ve yaygınlaştırılmasında kültür aktarıcılığı bağlamında önemli çalışmalar yapılmıştır. Fakat ürünün kültür endüstrisi alanına taşınması yerel ve zayıf kalmıştır. İlçede büyük işletmeler açılarak nokulun tüm ülkeye hatta dünyaya pazarlanmasında çeşitli girişimlere ihtiyaç duyulmaktadır. Bu bağlamda büyük gıda firmaları ile çeşitli anlaşmalar yapılarak üründen elde edilecek katma değerin artırılması sağlanabilir. Bu çalışmalara paralel olarak nokulu tanıtma ve yaşatma çalışmaları bağlamında çeşitli projeler yapılabilir. Yapılacak ulusal veya uluslar arası projeler bu ürünün imge ve marka haline gelmesine büyük katkı sağlayacaktır. 
Coğrafi işaretlerin tescillenmesi, kentsel belleğin, dolayısıyla yaratılan kent imgelerinin yasal ve etkili bir şekilde değerlendirilmesine katkı sağlayacaktır (Özdemir 2011: 52). Bu manada nokulun coğrafi işaret belgesi alması, kültürel ekonomik bir imge olarak üretilmesi ve ticarileşmesine büyük katk1 sağlayacaktır. Bu belge Bafra nokulu adıyla yapılacak bütün faaliyet, proje ve üretimlerin yasal dayanağını oluşturacaktır.

Nokulun kültürel bir imge olarak ticarileşmesi, günümüzde sıkça zikredilen kadın istihdamı konusunda önemli açılımlar yapacaktır. Geleneksel nokulun kadınlar tarafından yapılması, Bafra'daki nokul işletmelerinin ve çalışanların kadınlardan oluşması bunun göstergesidir. Bunun yanında ürünün büyük bir ticaret potansiyeline sahip olmas1, üründe kullanılan malzemelerin tedariği ve üretimini, bu manada istihdamı canlandıracaktır. Özellikle ceviz ihtiyac1, bölgenin köylerinde ceviz üretimini artıracak ve dolayısıyla cevizden ekonomik gelir elde etmeyi beraberinde getirecektir. Üzüm ihtiyacı da üzüm üretilen bölgelere aynı katkıyı sağlayacaktır. Artan ekonomik gelişme ve istihdam, sosyal refahı da beraberinde getirecektir. Nokuldan etkili bir şekilde yararlanmak kentin veya ülkelerin sürdürülebilir kalkınma sürecinin millî ayağına katkı sağlayacaktır. Özünel'e göre Birleşmiş Milletlerin sürdürülebilir kalkınma politikası dünya ülkelerini bir yandan yerli ve millî değerleri korumaya, diğer yandan evrensel olanları yakalamaya zorlamaktadır. $\mathrm{Bu}$ zorlu süreçte topluluğun miras yönetimine etkin katılımı sağlanmalıdır (2017: 21).

Küreselleşen dünyada kültürel kaynaklı üretim alışkanlıkları hızla artmaktadır. Böylece günümüz gastronomisinde yöresel yiyecekler tekrar değerli görülmeye başlamıştır. Fakat yöresel yiyecekten mevcut haliyle yüksek ekonomik gelir elde etmek imkânsızdır. Bu yüzden ürününün imgeleşmesi ve marka haline getirilmesi, pazarlanmasını ve katma değerini artırarak çok daha fazla gelir elde edilecektir. Aynı zamanda kültür unsuru da yaşatılmış olacaktır.

İmgeler, küreselleşme karşısında kültür turizminin hareket noktalarından biri olan yerelliğin değerlendirilmesi, ayrıca yerel unsurları küreselleştirerek yaşatma ve yerel kültürün yaşama alanını güçlendirme bakımından önemlidir (Oğuz 2002: 62). Doğal ve tarihi güzellikleri açısından potansiyeli olan Bafra'nın kültür turizmini de değerlendirmesi gerekir. Fakat bu turizm, sadece ekonomik bir kaygıyla tek taraflı değil, yerel kültürel ürünleri öne çıkaran, onların yapım süreçlerine de turistleri dâhil eden dinamik bir yapıda olmalıdır. Kültürel ürünlerin yapımında deneyimleme ve satış birlikte ele 
alınmalıdır. Bir ürünün imgeleşmesi ve marka haline gelmesinde deneyimlemenin büyük etkisi vardır. Bunun için kültür avcısı olarak da tanımlanan turistler hamur yuğurma, yufka açma, iç malzemesi hazırlama, hamura iç malzemesini katma, hamuru yoğurma ve üzerine yumurta sarısı sürme gibi nokul yapım süreçlerine dâhil edilmelidir. Bu uygulamalar, yöresel ürünlerin pazarlanması ve tanıtımı için ilgi çekici eylemlerdir.

Kentsel imge araştırmaları, coğrafi farklılıkların, özgünlüklerin ve zenginliklerin kentsel imge yaratımında ve gösteriminde doğal haliyle ya da işlenmiş bir şekilde kullanıldığını ortaya koymaktadır (Özdemir 2011: 48). Bafra nokulu doğal haliyle kullanılmakta olup işlenmiş/tasarlanmış bir şekli bulunmamaktadır. Bir ürünü imgeleştirmek ve marka değeri oluşturmak amacıyla nokulun farklı sanat dallarına aktarımı ve kullanımı da gerekmektedir. Örneğin Bafra için yapılan bir heykelde elinde nokul bulunan bir insan figürü, Bafra'nın resmedildiği noktalarda nokul üreten kadınlar, sinema veya dizilerde nokulun üretimi veya kendisi, edebi eserlerde nokula yer verilmesi bu açıdan son derece dikkate değer çalışmalar olacaktır. Özellikle müzik alanında kullanımı bu süreci hızlandıracaktır. Samsun'da ikamet eden şair ve besteci Kenan Yavuzarslan'ın söz ve müziği kendisine ait olan, Bafra imgelerinin bir kısmını dile getirdiği ve nokulun nakarat olarak sıklıkla tekrar edildiği türküsü, imgelerin şiirleştirilmesi/türküleştirilmesi bağlamında dikkate değer bir örnektir. Türküyü 2007 yılında yazdığını belirten Yavuzarslan, "Yedim Bafra nokulu/Ceviz üzüm kokulu/Anamı gönderecem (de)/Yar bitirsin okulu/Babamı gönderecem (de)/Yar bitirsin okulu" nakaratında âdeta Bafra nokulunu tescillendirmektedir. Zalpa'nın tanıtım videosunda nokulun tanıtımında bu türkü fon müziği olarak kullanılmıştır (https://www.youtube. com $/$ watch? $v=9$ Hb_FkuWEA0).

\section{Nokulu Geleceğe Taşıma Önerileri}

Bafra nokulu yakın zamanda coğrafi işaret tescil belgesi almış ve ilçede yapılan çalışmalarla imgeleşme yolunda adımlar atılmıştır. Fakat ilerlemelerin bir noktada tıkandığı, nokulun etki alanını genişletemediği, yörenin sosyokültürel hayatında yer edinmiş olsa da ticari ve turistik bağlamda bu üründen yeterince yararlanılamadığı görülmektedir. Oysa "Kentlerin kimliği, belirginleştirilen, vurgulanan, öne çıkarılan, ekonomik değere, markaya dönüştürülen imgelerinden hareketle oluşturulmaktadır." (Özdemir 2008: 18). Kültürel bellekte zengin malzemelere sahip olan Bafra'nın bu kaynaktan beslenerek sahip olduğu imgeleri değerlendirmesi ve modern kentin yaşam alanı 
içerisine dâhil etmesi gerekir. Bunun için yapılacak çok yönlü çalışmalarla yerel unsurlar önce ulusal alana taşınmalı, daha sonra uluslar arası sahada ülkenin bir markası konumuna getirilmelidir. Bunun için nokulun yerelde Bafra ve Samsun'un, genelde Türkiye'nin bir imgesi olduğu unutulmamalı ve çalışmalar bu bağlamda düzenlenmelidir. Nokulun yaygınlaşması, imge ve marka haline gelmesi için önereceğimiz bazı çalışmaları şöyle sıralayabiliriz:

Çoğu kent merkezinin girişinde kentlerin imgelerinin yer aldığı çeşitli heykeller, maketler veya temsiller yer alır. Kent imgelerinin tanıtılması bağlamında önemli bir yer tutan bu uygulamadan Bafra'nın da yararlanması gerekir. Bu açıdan ilçenin her iki giriş yerine nokulun da aralarında bulunduğu Bafra'nın sembolleri yapılmalıdır. Bunlar dikkat çekici büyüklükte ve şekilde tasarlanmalıdır.

Şehrin merkezinde uygulamalı halk bilimi müzesi kurulmalıdır. Burası yöre insanına ve dışarıdan gelen turistlere hitap etmelidir. Bafra'nın yöresel kent imgelerinin bizzat üretildiği bu mekânda misafirlerin üretim sürecini canlı olarak görmeleri, hatta bu süreci deneyimlemeleri gerekir.

İlçe merkezinde uluslar arası nitelikte "Nokul Festivali" gerçekleştirilmelidir. Festivale yöresel ve ulusal basın davet edilerek nokulun reklâmı yapılmalıdır. Bu festivalde çeşitli etkinlikler düzenlenmeli, insanların hem eğlenmesine hem de yöresel imgeleri tanımasına firsat verilmelidir. Örneğin "En iyi nokulu yapma yarışması" düzenlenerek nokul üreticileri yarıştırılmalı, en iyi nokul yapan insan gelecek yıla kadar "Nokul Güzeli' olarak seçilmelidir. Katılımcıları teşvik edici ödüller verilmelidir. Festival içerisinde ödüllü nokul yeme yarışması düzenlenmelidir.

İlçe merkezinde gerçekleştirilen Hıdrellez Şenlikleri, Sele Sepet Top Kandil Şenlikleri gibi yerel ve Kapıkaya Fest gibi ulusal şenlikler iyi değerlendirilmeli ve özellikle ilçe dışından gelen misafirlere nokul ikramları ile ürünün tanıtılmasına çalışılmalıdır. Hatta Samsun'un diğer ilçelerinde düzenlenen şenliklere, anma törenlerine ve festivallere nokul üreticileri katılarak ürünün yörede tanınması sağlanmalıdır. Eğlenme amaçlı bir araya gelen insanlar tanıtım için büyük bir firsat olarak görülmelidir.

Türkiye'nin çeşitli illerini gezen ve yöresel yemeklerini tanıtan gastronomi programlarının Samsun'a gelmeleri sağlanarak bu ürünlerin televizyon ekranlarında tanıtımına olanak sağlanmalıdır.

Milli Eğitim Bakanlığı ile görüşmeler yapılarak sağlıklı gıda ve beslenme 
ilkeleri kapsamında nokulun tekli kapalı paketlerde okul kantinlerde satışı sağlanmalıdır. Ayrıca yerli malı haftasında il içerisinde nokul tanıtımları ve ikramları yapılmalıdır.

Samsunspor'un maçlarında futbolcuların formalarında, stat içinde kentsel imgelerin reklamı yapılmalıdır. Bu uygulama ile spor camiasının nokulu tanımaları sağlanabilir.

Nokul şerbetsiz bir tatlı olduğu için Türkiye'de ulusal ve uluslar arası alanda faaliyet gösteren büyük otellerin tatlı menüsüne eklenerek ulusal ve uluslar arası düzeyde tanıtımı yapılmalıdır.

Samsun şehirler arası otobüs terminali ve Çarşamba Havaalanı gibi insan geçişlerinin yoğun olduğu yerlerde, reklam panolarında tanıtılabilir. Hatta otobüs ve uçakla seyahat edenlere tekli kapalı paketlerde ikram olarak verilebilir. Bunun için firmalarla anlaşmalar yapılabilir.

Küçük nokul işletmeleri birleşerek büyük şirketlere dönüşebilir. Çok izlenen televizyon programlarına tanıtım amaçlı reklam verilebilir. Sosyal medya etkin kullanılarak binlerce insanın nokulu tanımasına olanak sağlanabilir. 


\section{SONUÇ}

Küreselleşmeye karşı özgünlüklerin öneminin arttığ1 günümüz dünyasında, kültürel belleklere müracaat etme ve bu hazineleri değerlendirme ihtiyac1 doğmuştur. Belleklerde yer alan doğal veya işlenmiş ürünler, çeşitli şekillerde değerlendirilerek hem kültürel ekonomik bir imge olabilir hem de toplumların kültürlerinin yaşatılmasında etkin rol oynayabilir.

Samsun ili çok sayıda imgeye sahiptir ve bu açıdan Bafra ilçesi de önemli değerleri barındırmaktadır. Mutfak kültürünün bir ürünü olan nokul, Bafra’nın imgesi olma yolunda ilerlemekte, ürünün gelecek kuşaklara taşınması ve üretiminde önemli çalışmalar yapılmaktadır. Fakat özelde Bafra'nın, genelde Samsun'un imgesi olan nokulun ulusallaşması ve ülkemizin bir ürünü olabilmesi için daha büyük ölçekte çalışmalar yapılmalı ve çeşitli projeler üretilmelidir.

Bafra'nın sürdürülebilir kalkınma ve kadın istihdamında nokul başta olmak üzere yöresel ürünlerden yararlanması ve bunları kültürel ekonomik imgeye dönüştürmesi gerekmektedir. Ortak bellek ürünlerinin ticaret ve turizm alanlarında değerlendirilmesi, toplumların gelecekte bacasız sanayilerini inşa etmeleri bağlamında önemli bir adım olacaktır. Bunun için günümüz medya ve internet kaynaklarının, pazarlama stratejilerinin, imge ve markalaşma süreçlerinin iyi bilinmesi gerekir. Bafra nokulu çok yönlü çalışmalarla gelecekte kentlerin modern imgeleri bağlamında hak ettiği yeri alacaktır. Böylelikle yerel somut olmayan kültürel bir miras dünyanın bir değeri olarak kalıcı hale gelecektir. 


\section{KAYNAKLAR}

Bayat, Fuzulî (2008). Orta Türkçe Sözlük, İstanbul: Ötüken Yayınları.

Çağbayır, Yaşar (2007). Ötüken Türkçe Sözlük, İstanbul: Ötüken Neşriyat.

Eren, Hasan (1999). Türk Dilinin Etimolojik Sözlüğ̈̈, Ankara: Bizim Büro Basım Evi.

Genç, Nadide Afra; Seçim, Yılmaz (2019). "Sinop Yöresel Mutfağının Unutulmaya Yüz Tutmuş Tatlarının Değerlendirilmesi”, Karadeniz Uluslararası Bilimsel Dergi, S. 44, s. 302-319.

Kanar, Mehmet (2011). Eski Anadolu Türkçesi Sözlüğü, İstanbul, Say Yayınları.

Karaçar, Ercan; Sezen Doğancili, Olca; Ak, Sekan, Gastronomik Değerler Kapsamında Sinop Mutfağına Özgü Bir Değer: Nokul, 137-447 (file:///C:/Users/Exper/Downloads/ GastronomikDeerlerKapsamndaSinopMutfanazgBirDeerNokul.pdf)

Oğuz, M. Öcal (2002). Küreselleşme ve Uygulamalı Halkbilimi, Ankara: Akçağ Yayınları.

Oğuz, M. Öcal (2009). Somut Olmayan Kültürel Miras Nedir?,Ankara: Geleneksel Yayıncılık

Ölçer Özünel, Evrim (2013). "Yeni Miraslar ve Uluslararası Sözleşmelerde Sürdürülebilir Kalkınma Stratejileri”, Millî Folklor, S. 100, 14-30.

Ölçer Özünel, Evrim (2017). "İnsanlar, Gezegen ve Refah İçin Bir Eylem Planı: Somut Olmayan Kültürel Miras ve 2030 Sürdürülebilir Kalkınma Hedeflerine Eleştirel Yaklaşım", Millî Folklor, S. 116, 18-32.

Özdemir, Nebi (2008). "Kültürel Ekonomik İmge Olarak Nasreddin Hoca", Millî Folklor, S. 77, s.11-20.

Özdemir, Nebi (2011). "Kentlerin Gezgin İmgeleri veya Kent İmgeleri Giydirilen Otobüsler", Millî Folklor, S. 77, s.41-53.

Samsun Valiliği, (2011). Samsun, Seçil Ofset.

Türkiye'de Halk Ağzından Derleme Sözlüğ̈̈ (2009). C. IV, Ankara: Türk Dil Kurumu Yayınları.

Yılmaz, Havana Tuğçe (2019). Halk Kültürü Ürünleri Bağlamında Bafra İlçesi Kent İmgeleri, Ondokuz Mayıs Üniversitesi, Sosyal Bilimler Enstitüsü, Yayımlanmamış Yüksek Lisans Tezi. 
(https://online.turkpatent.gov.tr/trademarksearch/pub/trademark result\#trademark_result, erişim: 18.11.2020).

(https://www.youtube.com/watch?v=9Hb_FkuWEA0).zdemir,

\section{Kaynak Kişiler:}

Ferda Karagöl Demir, 66 yaşında, Bafra'da ikamet ediyor, lisans mezunu, emekli öğretmen, usta öğretici, Zalpa adlı işyerinin sahibi.

Hasan Yiğit, 66 yaşında, Bafra'da ikamet ediyor, üniversite mezunu, emekli.

Kenan Yavuzarslan, 48 yaşında, Samsun'da ikamet ediyor, orman mühendisi, Orman Genel Müdürlügünde çalışıyor.

Nuran Güngör, 51 yaşında, Bafra'da ikamet ediyor, önlisans mezunu, giyim, el sanatları ve yöresel mutfak uzman usta öğreticisi. 
Fotoğraflar:

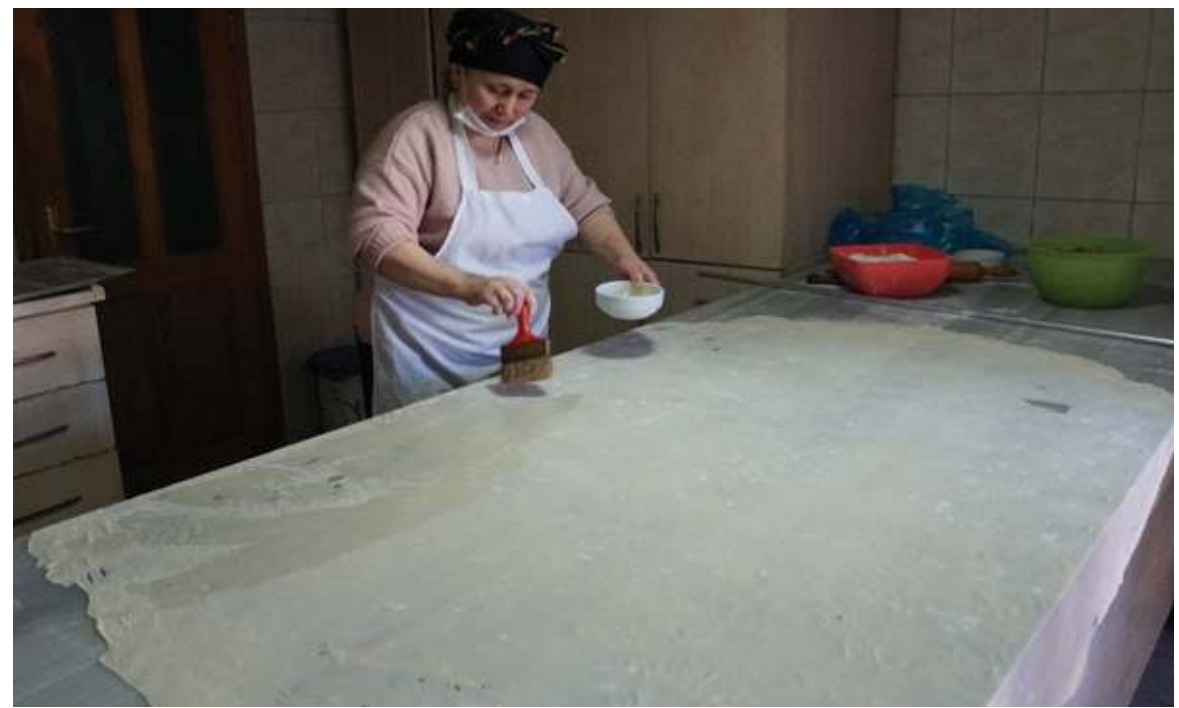

1. Fotoğraf: Çok ince açılan nokul hamurunun yağlanması.

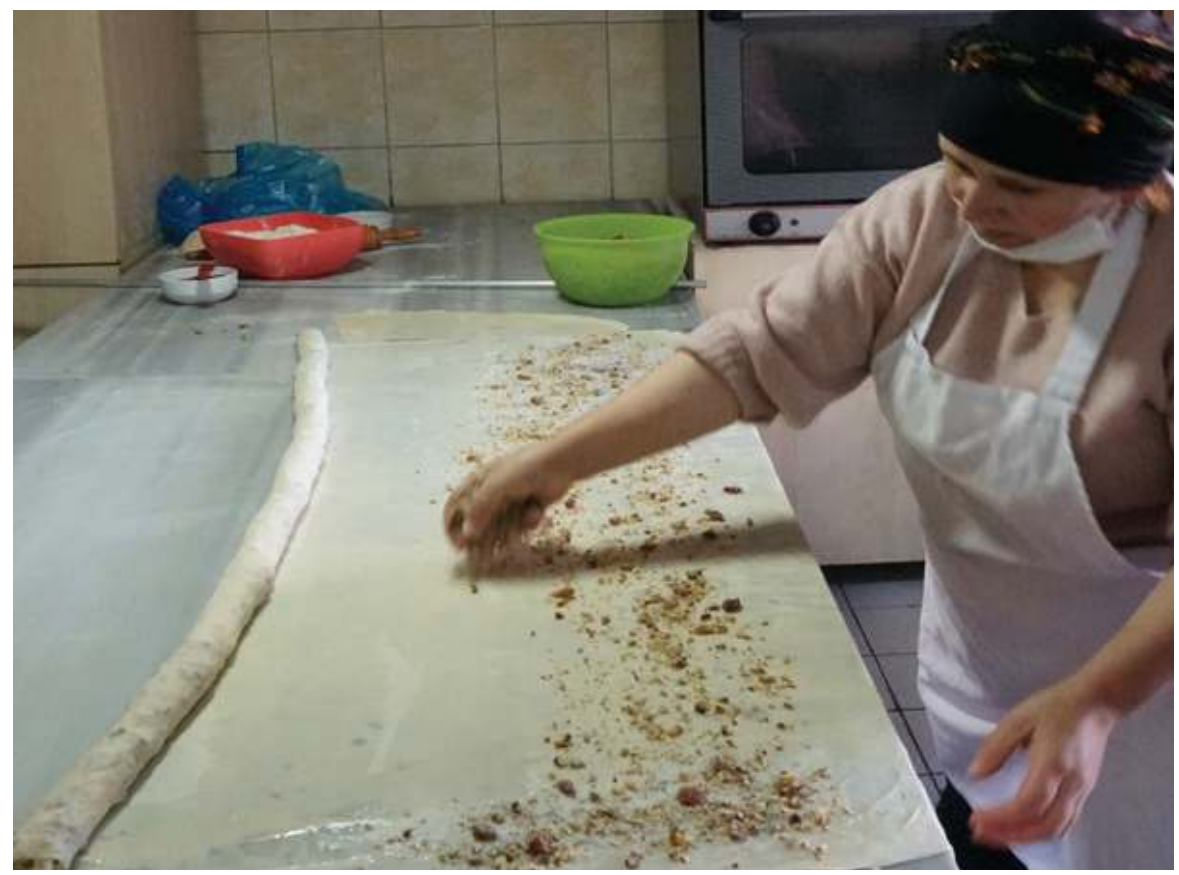

2. Fotoğraf: İç malzemenin açılan hamura serpiştirilmesi ve hamurun rulo haline getirilmesi. 


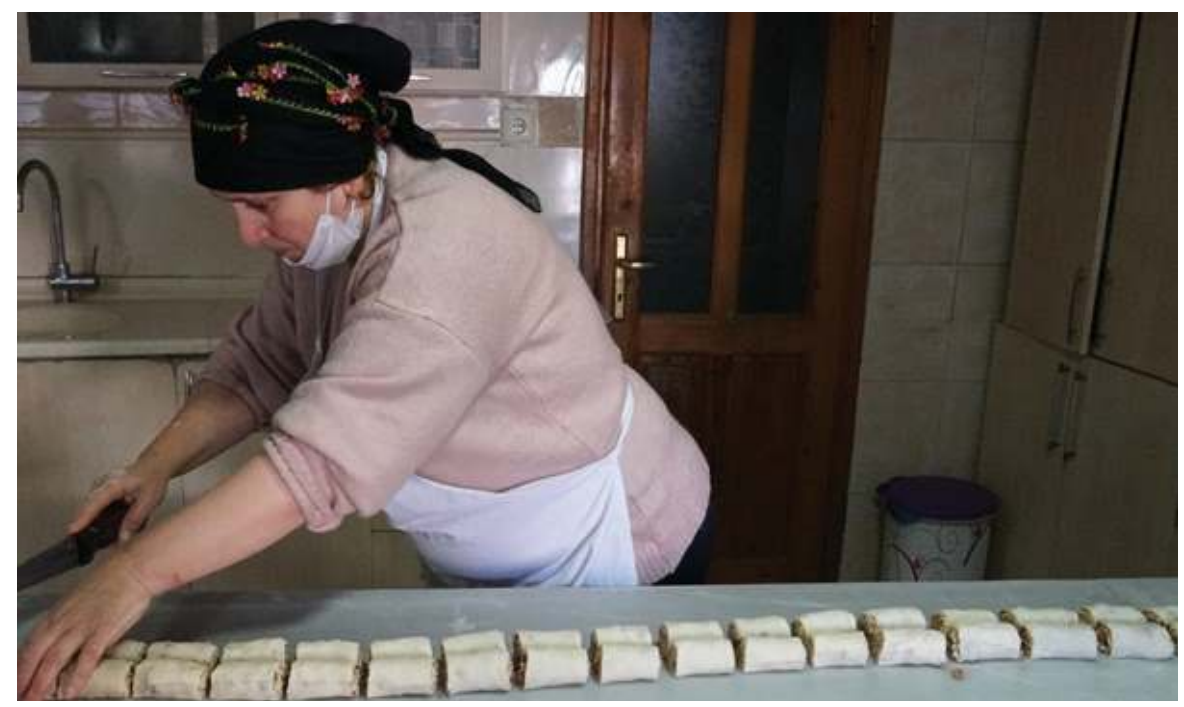

3. Fotoğraf: Rulo haline getirilmiş nokulların 7-8 cm uzunluğunda kesilmesi.

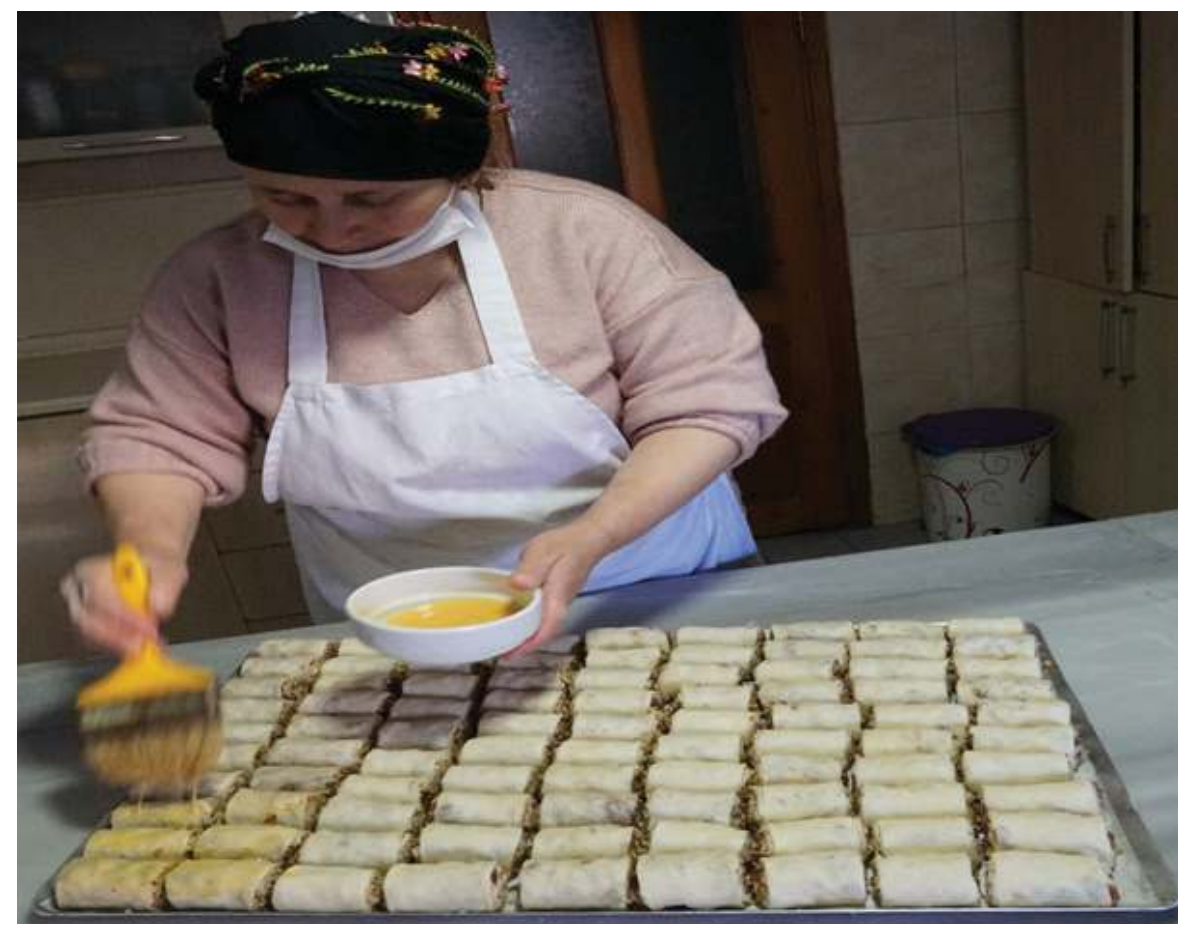

4. Fotoğraf: Nokulların üzerine yumurta sarısı sürülmesi. 


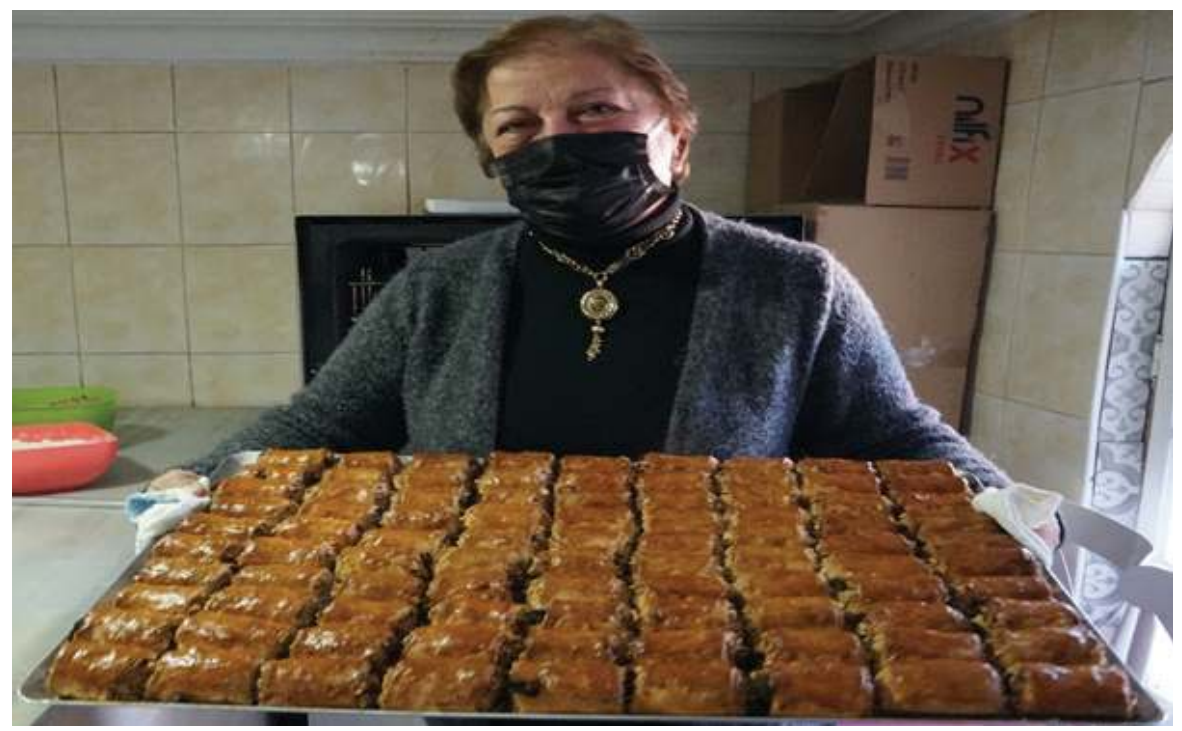

5. Fotoğraf: Fırında pişirilmiş nokullar.

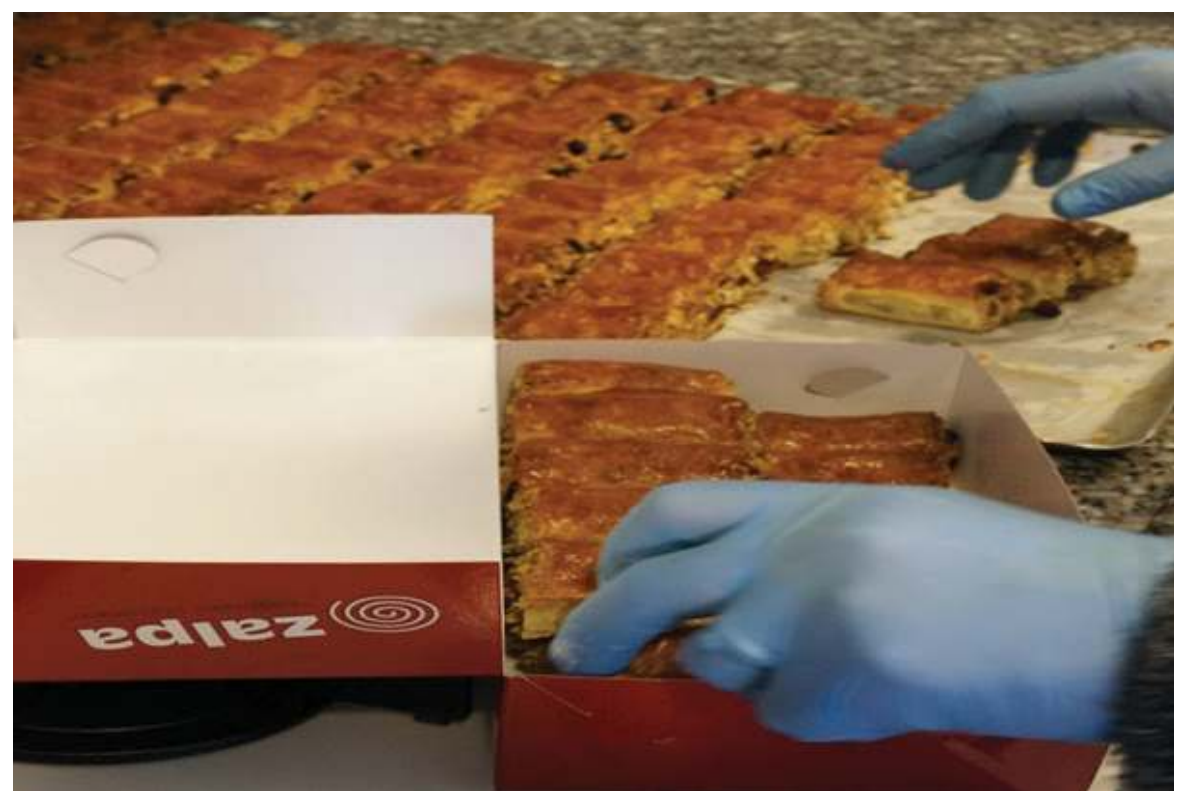

6. Fotoğraf: Nokulların özel hazırlanmış kutulara yerleştirilmesi. 


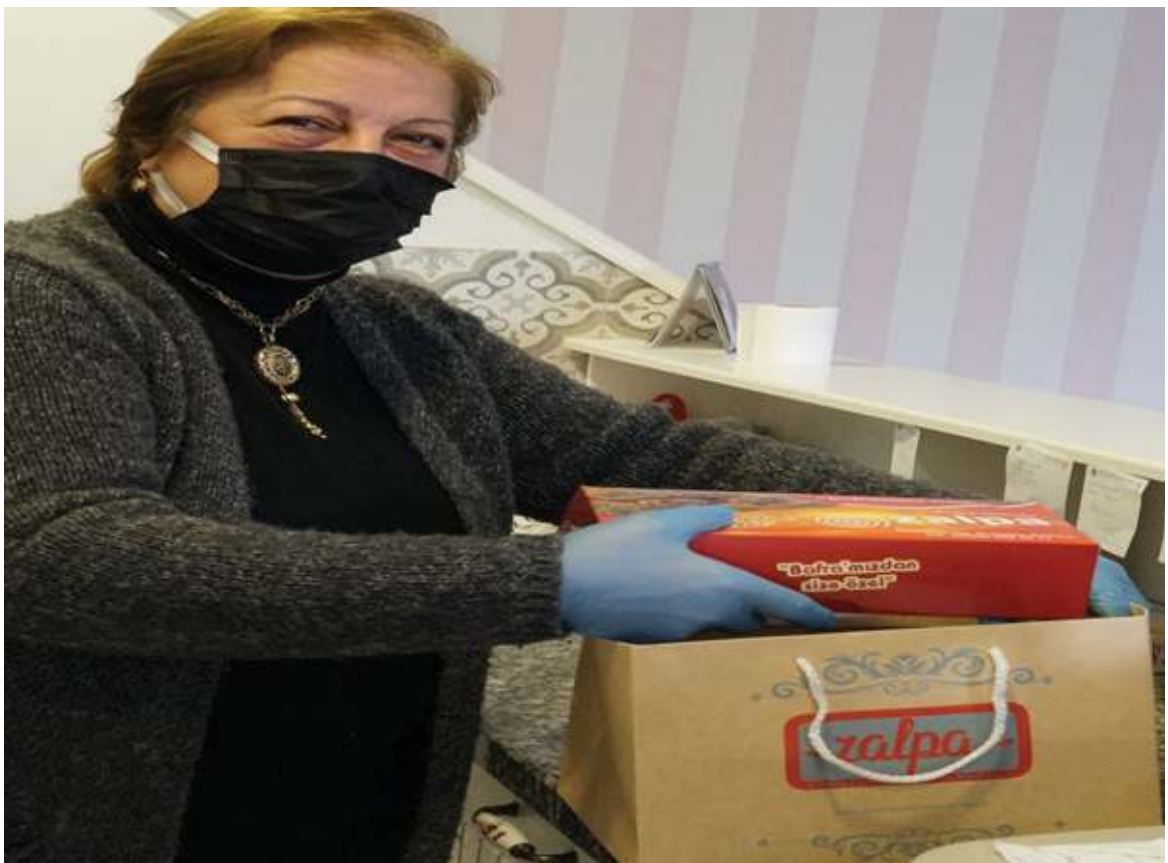

7. Fotoğraf: Firmanın adının yer aldığ 1 ve imgenin mekânına vurgu yapan kutular.

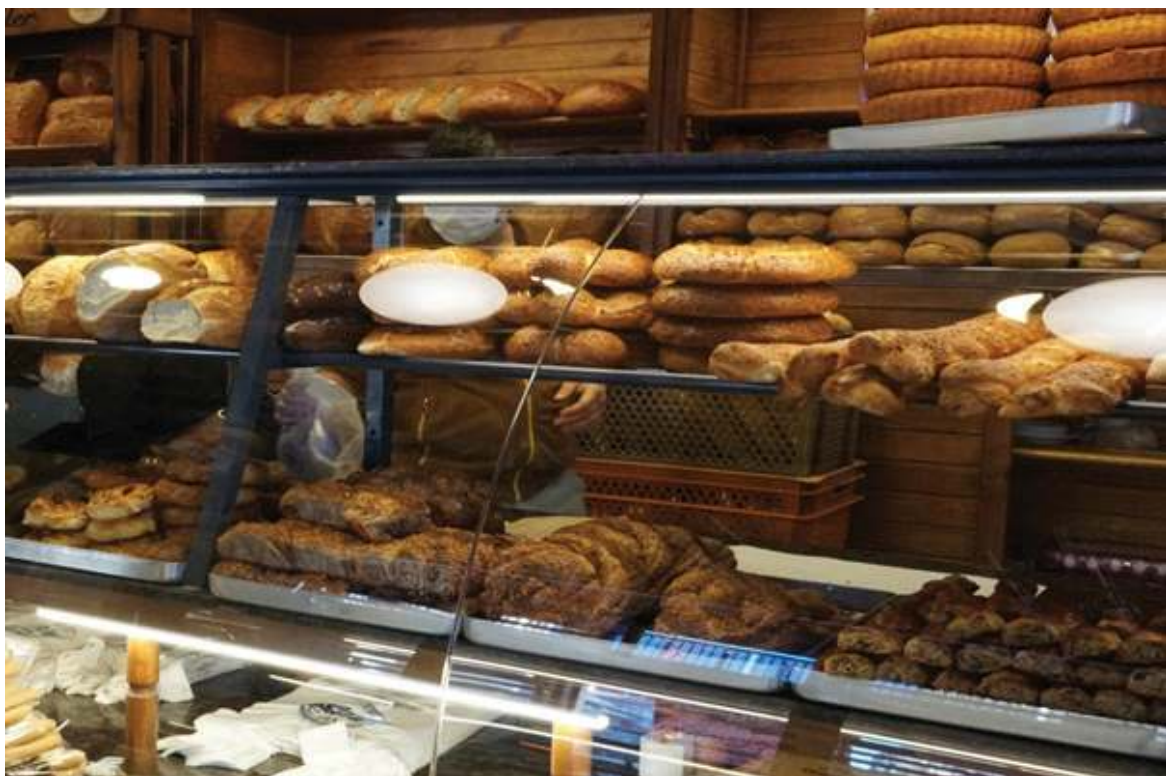

8. Fotoğraf: Bafra'da bir ekmek firınında satışa sunulan nokullar. 


\section{No: 227 - Mahreç IşaretI}

\section{BAFRA NOKULU}

\section{Tescil Ettiren SAMSUN BÜYÜKŞEHIR BELEDYYESI}

Bu cografi isaret, 6769 sayilı Sinai Molkiyet Kanunu kapsaminda 20.06.2012 tarihinden itibaren korunmak äzere 06.11 .2017 tarihinde tescil edilmiștir.

9. Bafra nokulu mahreç işareti belgesi. 
